\title{
Role of the Government in Development of Occupational Sports Organization in China
}

\author{
Hongquan Li, Houzhong Jin \& Guoying Yuan \\ Sports Economics and Management School, Central University of Finance and Economics \\ Beijing 100081, China \\ E-mail: lihongquan22@163.com,jinhouzhong@126.com \\ Chuanchuan Kong \& Li Lin \\ Beijing Sport University, Beijing 100084, China \\ E-mail: Kcc139@163.com
}

Received: March 1, $2011 \quad$ Accepted: March 21, $2011 \quad$ doi:10.5539/ass.v7n5p53

\begin{abstract}
This article employed document literature and comparative analysis method to sort out development skeleton of Chinese occupational sports organization and analyze the role of the government in development of Chinese occupational sports organization. According to the authors of this article, only if we establish the position of the government and practically play its due role, can the government provide vigorous guarantee for healthy development of Chinese occupational sports organization.
\end{abstract}

Keywords: Government, Occupational sports organization, Role

Occupational sports organization is an economic organization which provides competitive performance for audience with the method of market operation to realize its purpose of profits, mainly including occupational sports league and occupational sports club. For the time being, there are few studies on basic theory of occupational sports organization in China, especially studies on the role of the government in development of occupational sports organization in China. This, to a certain extent, affects relevant research on occupational sports organization.

\section{Status quo of its development}

Compared with European and American countries, China started late in its occupational sports. After 1992 when the national football work conference was held, football clubs of all varieties emerged one after another in China, which became an important stage in professionalization development of competitive sports. With its development for 17 years, the occupational sports in China have gone through a forming stage and turbulence stage. At present, the occupational sports are still at a turbulence stage. The major characteristics of occupational sports are as following: weak competitive force of league matches, bad institutional stability, low reputation, inconsistent targets of stakeholders of league matches and co-existence of administrative monopoly and market monopoly of league matches. Regarding the role of the government in development of occupational sports organization in China, since Chinese government has for a long time occupying an absolutely dominant position in the social and economic management system, it seems that the social power is relatively fragile. On one hand, the society depends too much on the government, and lacks the capacity of self-administration and self-restraint. On the other hand, the society does not have sufficient supervision on the government, so it is unlikely for the society to have a powerful strength to contend against with the government. This historical inertia has pushed forward the occupational sports development, which is still with strong official color and low marketization level. Here we just take transaction between occupational sports organizations and media institutions. As a result of the longitudinal administrative control of the news media, on one hand, free competition of the news field is restrained, and, on the other hand, there is no way for occupational sports organizations to operate broadcasting rights according to the market rules. Therefore, in development of occupational sports, only if the monopoly 
status of the government is changed, is it likely to break through the administrative monopoly situation of such industries as TV media, and to accelerate the developmental speed of occupational sports.

\section{Comparison between China and western countries}

In terms of construction of soft strength, western occupational sports organizations enhance their own competitive force by means of propagandizing and protecting their own image and building and maintaining their brands, etc., so as to intensify the appeal of the audience and their own influential power in the society. Compared with western occupational sports organizations, there is still a long way to go for Chinese occupational sports organizations in construction of such soft strength as management, operation, culture, brand, tradition and style, etc. In terms of the mode of interest distribution in the league matches, either investors and operators or consumers in western countries are experts in occupational sports, and have their own rights of voice to the quality and service of the products. Likewise, they may comment from head to feet and have their own different opinions on the level of a league match. Thus, owners, managers and athletes all have the rights of control over occupational sports organization and can share their achievements. By contrast, in China, relationship between individual event association and occupational sports club is to manage and to be managed. The goal of the sports event association is to enhance the competitive level of the national team of an sports event by means of the running of professionalization and to realize the goal of walking out of Asia and go to the world. However, the goal of occupational sports club is to promote the brand of an investing enterprise and realize maximization of utility. Goals of the associations and clubs deviate from each other. Therefore, definite conflicts exist between the distribution of their interests. In terms of stimulative system, mangers of occupational sports organizations in western countries regard the system of promotion and descending as a sort of stimulation mechanism, which effectively stimulates the excellent club and worst club in a league match. In Europe, sports tradition that has had a long time has already integrated sports into the daily life of people, and even a club with low level league match may possess extremely loyal fans and supporters. However, in China, since the market of demands is weak, the system of promotion and descending has bad effects on cultivation of the market, and is especially lacking in stimulation in cultivation of back-up talents.

\section{Role of the government}

\subsection{Enhancing management level of occupational sports organization}

For the time being, there exist quite a lot of elements that do not fit with development of modern organizations in management of occupational sports organization in China, which leads to low level of organizational management. In development of occupational sports organization, the government should make an attempt to reduce interference in occupational sports organization with administrative means. Then, on one hand, it is possible for occupational sports organization to allocate resources with the market means and really establish the market consciousness, economic consciousness and operation principle. The government should also support the occupational sports organization to improve its operation quality and realize sustainable development. On the other hand, the government ought to provide wider operation channels for occupational sports organization and allow for more operation means. Then, the government should offer excellent operation and management talents for development of occupational sports organization, give definite policy preferential treatment to institutions which foster professional talents in management and operation, encourage the society to cultivate batches of compound management talents who are proficient in operation and management and have comprehensive knowledge in developmental rules of occupational sports, enhance the management level of occupational sports organization and finally provide guarantee for sustainable development of occupational sports organization.

\subsection{Maintaining independence of occupational sports organization}

The government ought to reduce direct administration on occupational sports organization. In face with more complicated and pressing occupational sports development and reform, the government should transfer relevant management authority to occupational sports organization and enable the organization to be independent and autonomous to a certain extent. Occupational sports organization is in need of corresponding authority in order to conduct industrial management. Hence, the government ought to separate part of public management authority and entrust it to the industrial organization by a variety of means. In order to promote development of occupational sports organization and guarantee its independent status, the competent sports department of the government needs to ensure independence of occupational sports organization in activities of institutional setting and personnel allocation, etc. Only if an occupational sports organization has the right of autonomy, can it play the role of management innovation to the largest extent. 


\subsection{Reinforcing soft strength of occupational sports organization}

The government should seriously punish corruption of occupational sports organization, and guide occupational sports organization to lay emphasis on construction of soft strength. In our country, almost each competition of a league match is linked up with economic profit, and referees and athletes are placed in a deep market atmosphere all over the time. In a league match, the following events frequently occur: athletes lay siege to referees and play match fixing and referees blow a black whistle. Either occupational sports organization or club draws the outline of self image. Thus, the social public come to have common knowledge in occupational sports organization. Therefore, occupational sports organization has to pay attention to construction of its own image at any moment and build and strengthen a good image. This is not only obligation of occupational sports organization, but the government should also assume certain responsibility and obligation, since occupational sports organization has part of activities that serve for the society. Therefore, in order to let the public have an opportunity to see a positive image, the government has to seriously punish corruption in occupational sports organization and continuously enhance the image of occupational sports organization. This is the key for occupational sports organization to walk towards the international stage and intensify international appeal.

\section{Conclusion}

Chinese government takes up a leading position to a large extent in development of occupational sports organization in China. in the process of developing the occupational sports, we ought to borrow successful experiences of western countries, change the monopoly status of the government in development of occupational sports organization and strengthen the government role in enhancing the management level of occupational sports organization and maintaining independence of occupational sports organization.

\section{References}

Zhang, Jianli \& Jin, Houzhong, et al. (2008). On Government's Cultivation and Support for Professional Sports Organizations. Journal of Chengdu Sport University, (1).

Zhang, Jianli. (2004). Occupational Sports League and Relevant Legal Research. PHD Thesis of Beijing Sport University.

Zhang, Wenjian \& Li, Gang. (2006). The Innovation of Organizational Capital of Professional Sport. Journal of Beijing Sport University, 9(4):444-446. 